\title{
Genetic and Morphological Analysis of the Origin and Identity of Perennial Lavatera (Malvaceae) Cultivars
}

\author{
Mike L. Grant and Diana M. Miller \\ The Royal Horticultural Society, RHS Garden, Wisley, Woking, Surrey GU23 6QB, United Kingdom

\begin{abstract}
Centre for Plant Diversity and Systematics, Department of Botany, The University of Reading, Whiteknights, Reading RG6 6AS, United Kingdom
\end{abstract} \\ Alastair Culham
}

\begin{abstract}
ADDITIONAL INDEX WORDS. Lavatera olbia, Lavatera thuringiaca, RAPD, horticultural taxonomy, cultivar identification
Aвstract. Knowledge of the origin of Lavatera L. (tree mallows) cultivars helps to predict their cultural requirements. Eighteen accessions representing 15 cultivars, 14 accessions of 7 species, and 5 accessions of an $F_{1}$ hybrid between the putative parents of the cultivars were sampled for morphological variation and for randomly amplified polymorphic DNA (RAPD) fingerprint variation. Species-specific molecular markers were identified from the RAPD profiles. Chimeral elements were not distinguishable by RAPD analysis. Principal component analysis identified the majority of the cultivars to be selections of hybrid origin, probably from a narrow genetic base. Two cultivars were derived directly from individual species. The resolving power of RAPD markers and morphology was similar although RAPD data offered greater ability to ascribe parentage while morphology offered optimal discrimination of cultivar selections.
\end{abstract}

Shrubby Lavatera L. (tree mallows) are grown widely and have become popular garden plants (Hardy, 1997; Miller, 1999), especially since the introduction of 'Barnsley' in 1986 (Lancaster, 1987). Several species occur in cultivation although the majority of Lavatera grown are cultivars whose origin in relation to wild species is undocumented and their affinities are therefore uncertain. At least 15 cultivars are currently offered in the United States (Hill and Narizny, 2000) and over 20 in the United Kingdom (Lord et al., 2000). The species may be recognized quite easily using traditional morphological characters (Fernandes, 1968) although the generic circumscription is not so clear (Ray, 1995).

Uncertainty over the garden habit and performance of cultivars which nurseries list under one or other of the species, or simply under Lavatera is a result of arbitrary classification. This situation arose initially from lack of awareness of the differences between $L$. olbia $\mathrm{L}$. and $L$. thuringiaca $\mathrm{L}$. and the uncertain placement of the first cultivar, 'Rosea', which dates from before 1920 (Bean, 1970-80). Only one other cultivar, later named 'Kew Rose' (Cheek, 1989), was grown for the next 60 years or so until the arrival of 'Barnsley' stimulated selection and introduction of further cultivars in the late 1980s. As L. olbia is essentially shrubby in cultivation and L. thuringiaca is herbaceous, it is important to horticulturists that the cultivars are not assigned randomly to either species. It is also confusing if the same cultivar name is assigned to two different species, or none at all, in different publications.

Although a few cultivars have arisen as sports, many have been selected from open-pollinated seedlings which arise readily in a garden or nursery situation. These cultivars have been selected primarily on the basis of flower color (white to dark pink), flower size and petal spacing (Miller, 1999). They have

Received for publication 13 Nov. 1999. Accepted for publication 17 June 2001. We would like to thank Wendy Moore for valuable input during the early stages of this investigation, Carol Bazeley and Andy Rudnicki for technical assistance, James Compton and Simon Thornton-Wood for internal review of this manuscript, and the external reviewers who all made useful and constructive comments. The cost of publishing this paper was defrayed in part by the payment of page charges. Under postal regulations, this paper therefore must be hereby marked advertisement solely to indicate this fact. been attributed variously to L. olbia or L. thuringiaca (Cheek, 1989; Huxley, 1992; Lancaster, 1987, 1989) with little consensus to their true identity. Many do not match either species alone (Miller, 1997), implying that hybridization may have had a role in their origin (van de Laar, 1991). One of the cultivars, 'Barnsley', is thought to be a periclinal chimera (Cheek, 1989) and it regularly produces shoots from the base bearing flowers of the "core" color. The possibility of naturalized plants in the United Kingdom being of hybrid origin has also been suggested (Clement, 1998; Stace, 1997) and would be worth considering for those reported naturalized in Australia (Barker, 1977).

Reported chromosome counts of $2 \mathrm{n}=40$ (Davie, 1935) or $2 \mathrm{n}$ $=42$ (Luque and Devesa, 1986) for L. olbia and $2 \mathrm{n}=40$ (Bolkhovskikh, 1969), 2n = 42 (Markova and Goranova, 1993), or $2 n=44$ (Markova and Goranova, 1993) for L. thuringiaca are too close to offer the possibility of determining hybrids karyotypically. Other species grown occasionally in gardens can be discounted as possible parents on morphological grounds, but were included in our study for molecular comparison.

Randomly amplified polymorphic DNA (RAPD) markers (Welsh and McClelland, 1990; Williams et al., 1990) have been used widely to assess relatedness and distinguish genotypes in plants. The technique has been used with increasing success in the field of ornamental cultivars (Culham and Grant, 1999; Grant and Culham, 1997a,1997b; Kumar et al., 1998; Ling et al., 1997; Marquard et al., 1997; Walker and Werner, 1997) but may not be sensitive enough to distinguish somatic mutants (Wolff and Peters-Van Rijn, 1993).

The following reearch was undertaken to investigate the parental origin of cultivars and the role of hybridization in generation of Lavatera cultivars using artificial hybridization, RAPD markers, and morphological characters. In addition, the ability of RAPD markers to distinguish cultivars with a narrow genetic base was also evaluated.

\section{Materials and Methods}

Plant material. Material of L. olbia and L. thuringiaca was of documented wild origin, other species grown occasionally in gardens (L. arborea L., L. cachemiriana Cambess., L. maritima 
Gouan, and L. oblongifolia Boiss.) were from nursery sources (Table 1). Cultivars were, where possible, obtained from their originators (Table 1). Artificial $\mathrm{F}_{1}$ hybrids were produced between L. olbia and L. thuringiaca.. All accessions were field-grown in triplicate at the Royal Horticultural Society (RHS) Garden, Wisley, for 3 years. Voucher specimens were deposited in the Herbarium of RHS Garden, Wisley (WSY) or The University of Reading (RNG).

DNA EXTRACTION. About $1 \mathrm{~g}$ of leaf material was collected in July 1995 from each accession and DNA isolations were performed using the CTAB method, a DNA extraction protocol derived from Sambrook et al. (1989) and Doyle and Doyle (1987).

DNA extractions were quantified and dilutions to $3 \mathrm{ng} \cdot \mu \mathrm{L}^{-1}$ made with 'Nanopure' (Barnstead/Thermolyne, Dubuque, Iowa) water which were allowed a working life of 6 weeks. New stocks were prepared at the end of this period or following exhaustion of stock (which ever was first).
RAPD POLYMERASE CHAIN REACTION. Arbitrary primers 10 bases in length were obtained from the University of British Columbia, Vancouver, British Colombia, Canada, (no. 701-800) and used for polymerase chain reaction (PCR) amplification according to the protocol described by Williams et al. (1990). Each PCR reaction mix $(25 \mathrm{~mL})$ contained the following components/concentrations: $16 \mathrm{~mm}\left(\mathrm{NH}_{4}\right)_{2} \mathrm{SO}_{4}, 67 \mathrm{~mm}$ Tris-HCl, 0.1\% Tween-20, $2.5 \mathrm{~mm}$ $\mathrm{MgCl}_{2}, 0.2 \mathrm{~mm}$ each dNTP, with $0.1 \mathrm{~mm}$ of a single primer, $0.5 \mathrm{Unit}$ of TaqPolymerase and $1.5 \mathrm{ng}$ genomic DNA. Reactions were performed on a Hybaid Omnigene Thermocycler (Hybaid, Ashford, United Kingdom) in an air-conditioned laboratory (19 to $20^{\circ} \mathrm{C}$ ) using the following program: $2 \mathrm{~min}$ at $94^{\circ} \mathrm{C}, 39$ cycles each of 30 s at $93^{\circ} \mathrm{C}, 1 \mathrm{~min}$ at $42^{\circ} \mathrm{C}, 2 \mathrm{~min}$ at $72^{\circ} \mathrm{C}$, then cooled to $20^{\circ} \mathrm{C}$. Bands were separated on $1 \%$ agarose-TAE $\mathrm{pH} 8.0$ gels at $5 \mathrm{~V} \cdot \mathrm{cm}^{-1}$ for $2 \mathrm{~h}$ and visualized with ethidium bromide under ultraviolet light. One hundred base pair (bp) ladders (Promega, Southampon, United Kingdom) were used to estimate the size of the fragments.

Table 1. Details of plant material used in the study.

\begin{tabular}{|c|c|c|c|}
\hline Species/cultivar & Accession & Raiser/originator or collection location & Source \\
\hline L. olbia & 21 & Italy (collected by D.M.M.) & Liss Forest Nursery, Ltd. \\
\hline L. olbia & 22 & Italy (collected by D.M.M.) & Liss Forest Nursery, Ltd. \\
\hline L. olbia & 24 & Nursery stock acquired from Writtle Agr. College & Monksilver Nursery \\
\hline L. olbia & 26 & Nursery stock & Arne Herbs \\
\hline L. olbia & 40 & Morocco, Beni-Snassen (SLJ 15553) & University of Reading \\
\hline L. thuringiaca & 17 & S. Yugoslavia, Moraca Gorge (AL\&JS 90100JU) & Monksilver Nursery \\
\hline L. thuringiaca & 18 & S. Yugoslavia, Moraca Gorge (AL\&JS 90100JU) & D.M. Miller \\
\hline L. thuringiaca & 19 & Italy (collected by D.M.M.) & Liss Forest Nursery, Ltd. \\
\hline L. thuringiaca & 20 & Italy (collected by D.M.M.) & D.M. Miller \\
\hline L. olbia $\times$ L. thuringiaca & 33 & D.M. Miller (D.M.M. H1) & D.M. Miller \\
\hline L. olbia $\times$ L. thuringiaca & 34 & A.C. Leslie (ACL H1) & A.C. Leslie \\
\hline L. olbia $\times$ L. thuringiaca & 35 & A.C. Leslie (ACL H2) & A.C. Leslie \\
\hline L. olbia $\times$ L. thuringiaca & 36 & A.C. Leslie (ACL H3) & A.C. Leslie \\
\hline L. olbia $\times$ L. thuringiaca & 37 & A.C. Leslie (ACL H4) & A.C. Leslie \\
\hline L. arborea & 27 & South France & Perry's Plants \\
\hline L. arborea 'Variegata' & 25 & pre 1882 & Perry's Plants \\
\hline L. cachemiriana & 30 & Nursery stock & Perry's Plants \\
\hline L. maritima & 28 & Nursery stock & Burncoose and South Down Nurseries \\
\hline L. oblongifolia & 29 & Nursery stock & Madrona Nursery \\
\hline 'Barnsley' & 5 & Sport from 'Rosea' early 1970 s, discovered by R. Verey & Hopleys Plants, Ltd. \\
\hline 'Barnsley' & 6 & Sport from 'Rosea' early 1970s, discovered by R. Verey & R. Verey \\
\hline 'Barnsley' & 7 & Sport from 'Rosea' early 1970s, discovered by R. Verey & Monksilver Nursery \\
\hline 'Barnsley Perry's Dwarf' & 4 & Seedling from 'Barnsley', raised by P. Perry, Perry's Plants & Perry's Plants \\
\hline 'Blushing Bride' & 3 & Seedling from 'Barnsley', raised by G. Hellman & Acacia Nurseries \\
\hline 'Bredon Springs' & 12 & R Sidwell, Bredon Springs & Notcutts Nurseries \\
\hline 'Bressingham Pink' & 11 & Seedling raised by Blooms & Blooms of Bressingham, Ltd. \\
\hline 'Burgundy Wine' & 16 & Seedling selected by P. Catt, Liss Forest Nursery, Ltd. & Liss Forest Nursery, Ltd. \\
\hline 'Candy Floss' & 10 & Seedling selected by P. Catt, Liss Forest Nursery, Ltd. & Liss Forest Nursery, Ltd. \\
\hline 'Ice Cool' & 1 & Seedling selected by P. Catt, Liss Forest Nursery, Ltd. & Liss Forest Nursery, Ltd. \\
\hline 'Kew Rose' & 15 & First recorded from Ramparts Nursery & Royal Botanic Gardens, Kew \\
\hline 'Lara Rose' & 32 & Raised by G.J. Allen & G.J. Allen \\
\hline 'Pink Frills' & 8 & Discovered by Botanic Nursery in a public garden & Hopleys Plants, Ltd. \\
\hline 'Pink Frills' & 9 & Discovered by Botanic Nursery in a public garden & Liss Forest Nursery \\
\hline 'Rosea' & 14 & B. Ladhams, Ltd., The Shirley Nurseries, Southampton & Carlile's Hardy Plants \\
\hline 'Saxtead' & 31 & Introduced by Notcutts & Notcutts Nurseries \\
\hline 'Shorty' & 2 & Sport from 'Rosea', raised by Langthorns Plantery & Burncoose and South Down Nurseries \\
\hline 'Wembdon Variegated' & 13 & Sport from 'Rosea', raised by M. Cheek & R. Cheek \\
\hline \multicolumn{4}{|l|}{ 'Barnsley P.D.' (Accn.4) } \\
\hline rootsucker & 38 & Arose during present investigation & --- \\
\hline \multicolumn{4}{|l|}{ ‘Barnsley' (Accn. 5) } \\
\hline rootsucker & 39 & Arose during present investigation & --- \\
\hline
\end{tabular}




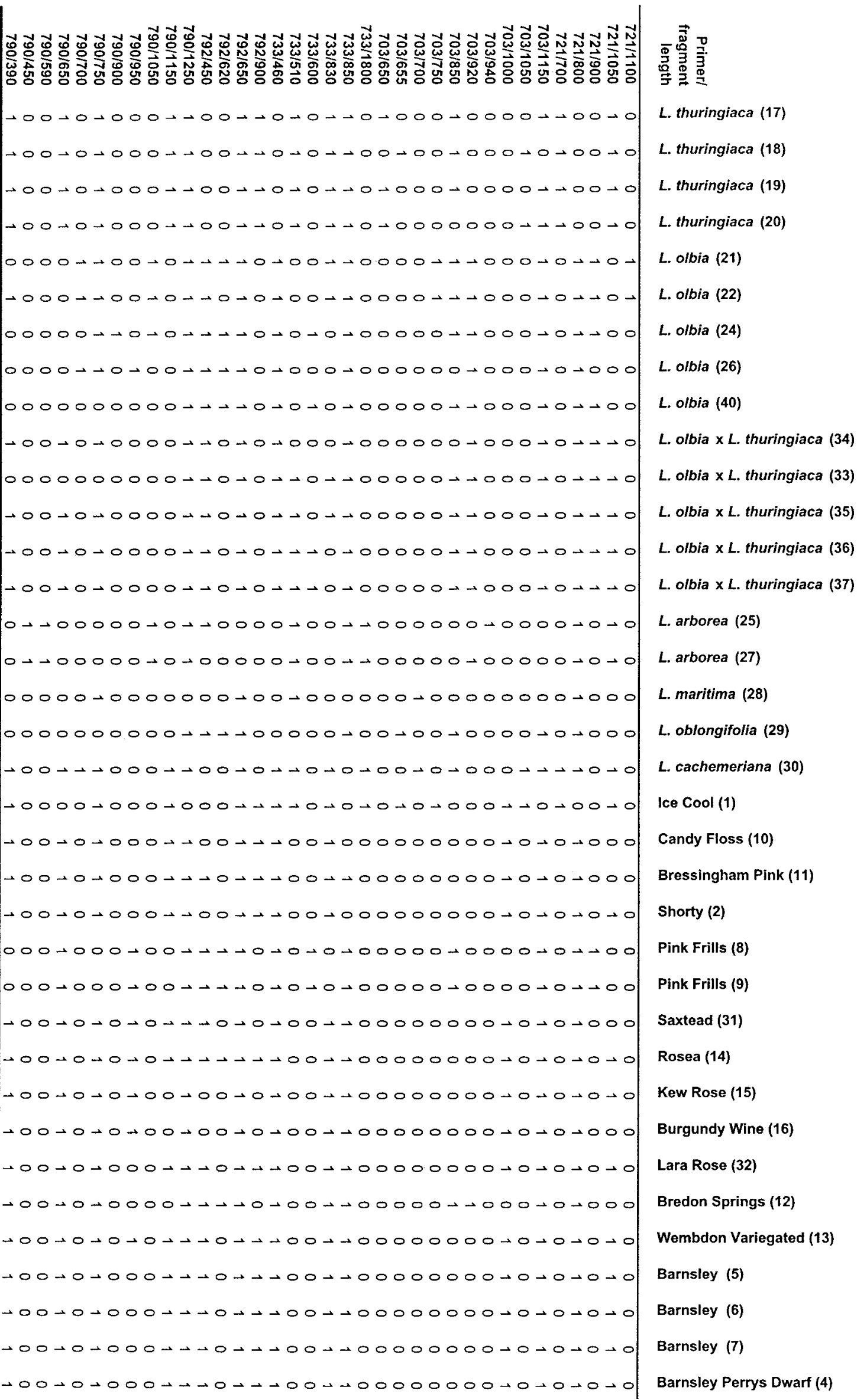


In total, 100 RAPD primers were screened to identify primers for taxon specific markers for Lavatera and to assess cultivar variation, and 17 were selected for use on a limited number of accessions (University of British Columbia 703, 708, 711, 721, 731, 732, 733, $736,743,744,745,747,751,774,790,792$, and 796). It was found that five were sufficient to distinguish the cultivars (University of British Columbia 703, 721, 733, 790, and 792) (Table 2). All reactions were triplicated and only reproducible bands were considered for this study.

GeL SCORING AND PRINCIPAL COMPONENT ANALYSIS. Gels were scored for the presence (1) or absence (0) of fragments. Principal component analysis was performed using the NTSYS-pc software package (Rohlf, 1992). In addition the data matrix was screened for species specific markers for L. olbia and L. thuringiaca using the wild origin material.

MorPHOLOGICAL ASSESSMENT. Winter habit was recorded as being herbaceous (plant dying back to ground level in winter) or shrubby (woody framework persisting). Where possible, five organs were measured from each of the accessions which were grown in triplicate $(\mathrm{n}=15)$ and means were calculated. Calyx and epicalyx areas $\left(\mathrm{mm}^{2}\right)$ were measured in flowers and in fruit using the DeltaT Image Analysis System version 1.12 software (Delta-T Devices, Ltd, 1993). Degree of expansion for both was calculated (mean area in fruit divided by mean area in flower). Pedicel length was measured in fruit. Hairiness of mature mericarps was assessed on the following scale: $0=$ glabrous, $1=$ few hairs at apex, $2=$ scattered hairs, 3 = sparsely hairy, and $4=$ densely hairy.

MoRPHOLOGICAL DATA ANALYSIS. The morphological data matrix was subjected to principal component analysis using the NTSYS-pc software package (Rohlf, 1992).

\section{Results and Discussion}

Typical DNA yields were in the region of 10 to $40 \mathrm{mg} \cdot \mathrm{g}^{-1}$ of leaf tissue. Under the stated PCR conditions, $1.5 \mathrm{ng}$ of DNA template was found to yield the best results for reliable and repeatable amplification and to maximize the scorable bands.

Of the 100 primers screened, 17 revealed polymorphisms between at least two of the taxa. The number of variable bands per primer was found to range from 1 to 11 with an average of 4.5 (e.g., Table 2). Band frequencies varied from $3 \%$ to $95 \%$ with an average of $53 \%$.

The morphological characters recorded showed variation within the wild species but little variation within cultivars. The cultivars were generally intermediate in morphology between the species (Table 3).

HYBRIDITY DETERMINED FROM GENOTYPIC CHARACTERS. The artificial $\mathrm{F}_{1}$ hybrids showed a high proportion of band sharing (92\%). The parents, L. olbia and L. thuringiaca, share an average of $81 \%$ and $93 \%$, respectively, within the individuals screened, and $76 \%$ and $68 \%$, respectively, with the hybrids. The cultivars demonstrate a high percentage of band sharing with the postulated parent species. Within the major group of hybrid cultivars, band sharing is $92 \%$. This group shows a $66 \%$ similarity to $L$. olbia, a $73 \%$ similarity to L. thuringiaca, and a $77 \%$ similarity to the artificial $\mathrm{F}_{1}$ hybrids.

MoleCUlAR MARKERS. Nine RAPD markers for $L$. olbia and $L$. thuringiaca were identified. Two bands (UBC 721700 bp, UBC $792900 \mathrm{bp}$ ) were unique to L. thuringiaca and two (UBC 790 1150 bp, UBC 790650 bp) shared with only L. cachemeriana, which is considered the most closely related species. One further

Table 3. Morphological data matrix. For explanation of characters measured see Morphological Assessment paragraph.

\begin{tabular}{|c|c|c|c|c|c|c|}
\hline Accession & $\begin{array}{l}\text { Cultivar/ } \\
\text { species }\end{array}$ & $\begin{array}{c}\text { Calyx } \\
\text { expansion } \\
\left(\mathrm{mm}^{2}\right)\end{array}$ & $\begin{array}{l}\text { Epicalyx } \\
\text { expansion } \\
\left(\mathrm{mm}^{2}\right)\end{array}$ & $\begin{array}{l}\text { Mericarp } \\
\text { hairiness }^{\mathrm{z}}\end{array}$ & $\begin{array}{l}\text { uit pedic } \\
\text { length } \\
(\mathrm{mm})\end{array}$ & $\begin{array}{l}\text { Winter } \\
\text { habit }^{y}\end{array}$ \\
\hline 1 & 'Ice Cool' & 2.2 & 1.7 & 0 & 23.2 & $\mathrm{H}$ \\
\hline 2 & 'Shorty' & 1.8 & 1.7 & 1 & 17.0 & $\mathrm{~S}$ \\
\hline 3 & 'Blushing Bride' & 1.5 & 1.4 & 1 & 12.4 & $S$ \\
\hline 4 & 'Barnsley Perry's Dwarf' & 1.3 & 1.4 & 1 & 12.5 & $S$ \\
\hline 5 & 'Barnsley' & 1.3 & 1.3 & 1 & 11.8 & $S$ \\
\hline 6 & 'Barnsley' & 1.3 & 1.5 & 1 & 11.1 & $\mathrm{~S}$ \\
\hline 7 & 'Barnsley' & 1.3 & 1.4 & 1 & 13.7 & $S$ \\
\hline 8 & 'Pink Frills' & 1.2 & 1.3 & 4 & 3.2 & $S$ \\
\hline 9 & 'Pink Frills' & 1.3 & 1.4 & 4 & 3.1 & S \\
\hline 10 & 'Candy Floss' & 1.3 & 2.8 & 1 & 19.6 & $\mathrm{H}$ \\
\hline 11 & 'Bressingham Pink' & 1.3 & 1.5 & 1 & 12.1 & $\mathrm{~S}$ \\
\hline 12 & 'Bredon Springs' & 1.8 & 1.7 & 3 & 8.3 & S \\
\hline 13 & 'Wembdon Variegated' & 1.4 & 1.5 & 2 & 16.7 & S \\
\hline 14 & 'Rosea' & 1.4 & 1.5 & 1 & 12.9 & $S$ \\
\hline 15 & 'Kew Rose' & 1.3 & 1.3 & 3 & 12.2 & S \\
\hline 16 & 'Burgundy Wine' & 1.4 & 1.2 & 2 & 8.2 & $S$ \\
\hline 17 & L. thuringiaca & 3.7 & 2.6 & 1 & 14.2 & $\mathrm{H}$ \\
\hline 18 & L. thuringiaca & 3.9 & 2.5 & 1 & 22.7 & $\mathrm{H}$ \\
\hline 19 & L. thuringiaca & 3.1 & 2.9 & 0 & 16.3 & $\mathrm{H}$ \\
\hline 20 & L. thuringiaca & 2.8 & 2.9 & 0 & 11.2 & $\mathrm{H}$ \\
\hline 21 & L. olbia & 1.3 & 1.2 & 4 & 6.2 & $S$ \\
\hline 24 & L. olbia & 1.6 & 1.4 & 4 & 4.6 & S \\
\hline 34 & L. thuringiaca $\times$ L. olbia & 1.3 & 1.4 & 1 & 7.8 & S \\
\hline 35 & L. thuringiaca $\times$ L. olbia & 1.5 & 1.6 & 2 & 9.2 & S \\
\hline
\end{tabular}

${ }^{\mathrm{z}}$ Assessed on a scale of 0 to 4 where $0=$ glabrous, $1=$ few hairs at apex, $2=$ scattered hairs, $3=$ sparsely hairy, and $4=$ densely hairy.

${ }^{{ }^{H}} \mathrm{H}=$ herbaceous (plant dying back to ground level in winter) and $\mathrm{S}=$ shrubby (woody framework persisting). 

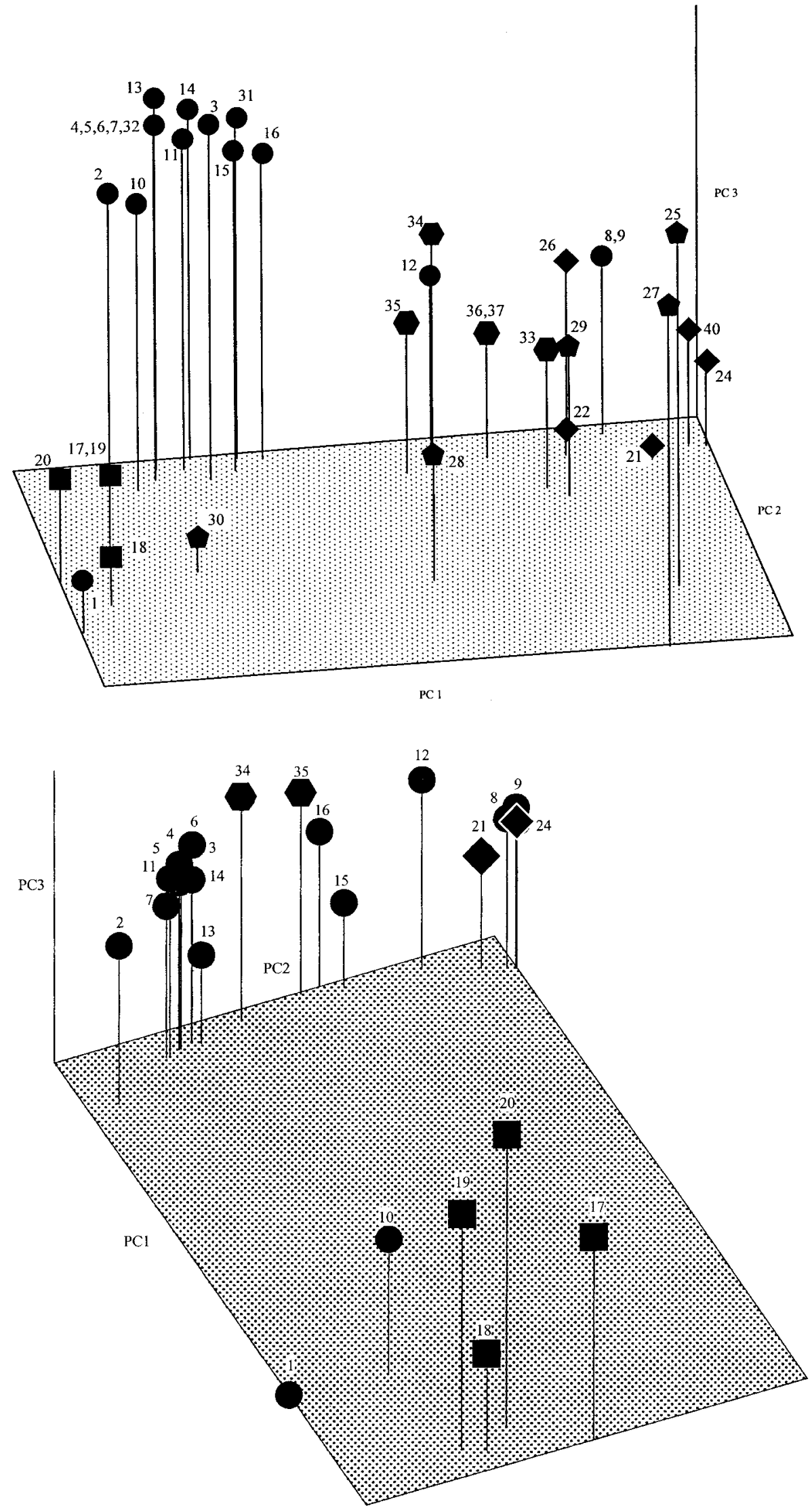

Fig. 1. Principal component (PC) analysis of combined RAPDdata for all 36 bands and 37 accessions listed in Table 2. $\diamond=L$ olbia, $\boldsymbol{\square}=$ L. thuringiaca, hexagon $=L$. olbia $\times L$. thuringiaca, pentagon $=$ other species, and $=$ cultivars.

marker (UBC $7211050 \mathrm{bp}$ ) is present in $L$. thuringiaca and $L$. arborea only and serves to distinguish further the former species from L. olbia. In contrast, L. olbia has no unique bands but does possess a unique absence of band UBC 733510 bp. Lavatera olbia also shares markers (UBC 703920 bp, UBC 721 $800 \mathrm{bp}$, and UBC $733460 \mathrm{bp}$ ) with other congeners that distinguish it from $L$. thuringiaca.

Phenotypic Characters. Morphological observations on the taxa relevant to the issue of hybridity showed the majority of cultivars to be intermediate between $L$. olbia and $L$. thuringiaca. Lavatera olbia is typically shrubby in habit whereas $L$. thuringiaca is typically herbaceous. 'Candy Floss' and 'Ice Cool' were also found to be herbaceous whereas all the deliberately raised hybrids and the rest of the cultivars were shrubby.

Lavatera thuringiaca showed the greatest increase in both calyx and epicalyx area from flower to fruit - an average increase of 3.4 times for calyx and 2.7 times for epicalyx. For L. olbia, the increases averaged 1.5 times and 1.3 times, respectively. The majority of cultivars and the deliberate hybrids remained closer to $L$. olbia for both these characters although 'Bredon Springs', 'Candy Floss', 'Ice Cool', and 'Shorty' all showed increases closer to $L$. thuringiaca in magnitude.

Fruit pedicel length in fruit averaged 16.1 $\mathrm{mm}$ for $L$. thuringiaca and $5.4 \mathrm{~mm}$ for $L$. olbia. The deliberate hybrids averaged 8.5 $\mathrm{mm}$ and the majority of the cultivars fell into the range of 8.2 to $16.7 \mathrm{~mm}$. The exceptions were 'Pink Frills' with an average of $3.1 \mathrm{~mm}$ and 'Shorty', 'Candy Floss', and 'Ice Cool' with averages of $17.0 \mathrm{~mm}, 19.6 \mathrm{~mm}$, and 23.2 $\mathrm{mm}$, respectively.

Mericarp hairiness was found to be densest (densely hairy $=4$ ) in L. olbia and absent (glabrous $=0$ ), or nearly so, in L. thuringiaca. Of the cultivars, only 'Pink Frills' (densely hairy $=4$ ) matched the hairiness of L. olbia and only 'Ice Cool' (glabrous $=0$ ) was as glabrous as $L$. thuringiaca. The deliberate hybrids and the rest of the cultivars fell between 1 and 3 on the scale.

CULTIVAR DISTINCTION DETERMINED FROM GENOTYPIC CHARACTERS. 'Pink Frills' and 'Ice Cool' are genetically distinct from the other cultivars, and can be attributed to L. olbia and L. thuringiaca, respectively (Fig. 1). The remainder fall somewhere between the two species with a group of cultivars forming a

Fig. 2. Principal component $(\mathrm{PC})$ analysis of morphological data for four quantitative and one qualitative character and 24 accessions listed in Table $3 . \bullet=L$. olbia, $=L$. thuringiaca, hexagon $=L$. olbia $\times$ L. thuringiaca, and $\mathbf{O}=$ cultivars. closely related core. This core group consists of 'Barnsley', 'Barnsley Perry's Dwarf', 'Blushing Bride', 'Bressingham Pink', 'Lara Rose', 
'Rosea' and 'Wembdon Variegated'. Some are indistinguishable using the RAPD markers employed in this study.

CULTIVAR DISTINCTION DETERMINED FROM PHENOTYPIC CHARACTERS. 'Pink Frills', 'Candy Floss', and 'Ice Cool' are distinct from the other cultivars in terms of morphological characters used for distinguishing the species (Fig. 2). 'Pink Frills' groups with L. olbia while the other two group with $L$. thuringiaca. The remainder form a more homogenous group that can be distinguished by a combination of flower color, and petal size and arrangement. These additional features are a result of artificial selection of garden material and many of the characteristics have originated from somaclonal mutation that is not predictive of parentage. These morphological differences are explored more fully in Miller (1999).

Distinction OF CHIMERAL ELEMENTS. No genotypic polymorphisms in 'Barnsley' or 'Barnsley Perry's Dwarf' were discernible between the normal shoots (bearing white flowers with a pink eye) and the root-origin shoots (bearing pink flowers). This suggests that RAPD markers are not sensitive enough to detect what may be only a single gene mutation affecting flower color.

\section{Conclusions}

Results indicate that 'Ice Cool' is derived from L. thuringiaca and 'Pink Frills' from L. olbia. The other cultivars are hybrids falling between these two species for which a name, L. x clementii Cheek, has recently been published (Cheek, 2000). A distinct clustering of closely related cultivars suggests that they have arisen from a relatively closed gene pool probably derived from the two commonest and oldest cultivars, 'Rosea' and 'Kew Rose'. The genetic position of the hybrids raised deliberately for this study from wildorigin parents is intermediate, but they cluster in a different area of the graph to the cultivars indicating their possession of a novel origin. Morphological data were congruent with the molecular results but the characters identifying parentage were not good at distinguishing the cultivars. Novel morphological elements selected in cultivation such as flower color, flower size and petal spacing are necessary for cultivar distinction (Miller, 1999). Molecular markers to the putative parents were successfully identified and could be used in determination of the parentage of the cultivars.

\section{Literature Cited}

Barker, W.R. 1977. The species of Malva and Lavatera (Malvaceae) naturalized in south Australia. J. Adelaide Botanic Gardens 1:107-114.

Bean, W.J. (1970-1980) Trees and shrubs hardy in the British Isles. vols 14. $8^{\text {th }}$ ed. John Murray, London.

Bolkhovskikh, Z., V. Grif, T. Matvejeva, and D. Zarharyeva. 1969. Chromosome Numbers of Flowering Plants. USSR Academy of Sciences, Leningrad.

Cheek, M. 1989. The Lavatera imbroglio. The Garden 114:23-27.

Cheek, M. 2000. A new name for a European Lavatera (Malvaceae). Kew Bul. 55:1013-1014.

Clement, E. 1998. Lavatera olbia $\times$ L. thuringiaca does occur in Britain. Botanical Soc. of the British Isles News 78:59-60.

Culham, A. and M. Grant. 1999. DNA markers for cultivar identification and classification, p. 183-198. In: S. Andrews, A.C. Leslie, and C. Alexander (eds.). Taxonomy of cultivated plants. Royal Botanic Gardens, Kew, United Kingdom.

Davie, J.H. 1935. Chromosome studies in the Malvaceae and certain related families II. Genetica 17:487-498.

Delta-T Devices Ltd. 1993. Delta-T image analysis system version 1.12. Delta-T Devices Ltd, Cambridge, United Kingdom.

Doyle, J.J. and J.L. Doyle. 1987. A rapid DNA isolation procedure for small quantities of fresh leaf tissue. Phytochem. Bul. 19:11-15.

Fernandes, R. 1968.Lavatera L.p. 251-253.In:T.G.Tutin, V.H.Heywood, N.A. Burges, D.M. Moore, D.H. Valentine, S.M. Walters, and D.A. Webb (eds.). Flora Europaea. vol. 2. Cambridge Univ. Press, Cambridge, United Kingdom.

Grant, M. and A. Culham. 1997a. DNA fingerprinting and the identification of ornamental cultivars. The New Plantsman 4:85-87.

Grant, M. and A. Culham. 1997b. DNA fingerprinting and the identification of ornamental cultivars: Part 2. The New Plantsman 4:157-168.

Hardy, R. 1997. Sweet mallows. Gardens Illustrated 25:52-58.

Hill, S. and S. Narizny. 2000. The Pacific Northwest plant locator 20002001. Black-Eyed Susans Press, Portland, Ore.

Huxley, A. (ed.). 1992. The new Royal Horticultural Society dictionary of gardening. Macmillan, London.

Kumar, P.P., C.K.Y. Yau, and C.J. Goh. 1998. Genetic analysis of Heliconia species and cultivars with randomly amplified polymorphic DNA (RAPD) markers. J. Amer. Soc. Hort. Sci. 123:91-97.

Lancaster, R. 1987. Award plants 1986. Part 3. The Garden 112:558-561. Lancaster, R. 1989. Award plants 1988. Part 2. The Garden 114:253-258.

Ling, J.T., R. Sauve, and N. Gawel. 1997. Identification of poinsettia cultivars using RAPD markers. HortScience 32:122-124.

Lord, T., J. Cubey, M. Grant, and A. Whiteley (eds.). 2000. RHS plant finder 2000-2001. Dorling Kindersley, London.

Luque, T. and J.A. Devesa. 1986. Contribucion al estudio citotaxonomico del genero Lavatera (Malvaceae) en Espana. Lagascalia 14:227-239.

Markova, M.L. and V.Y. Goranova. 1993. Karyological study of representatives of family Malvaceae in Bulgaria. Fitologija 46:12-32

Marquard, R.D., E.P. Davis, and E.L. Stowe. 1997. Genetic diversity among witchhazel cultivars based on randomly amplified polymorphic DNA markers. J. Amer. Soc. Hort. Sci. 122:529-535.

Miller, D.M. 1997. Lavatera L., p. 215-217. In: J.Cullen, J.C.M. Alexander, C.D. Brickell, J.R. Edmondson, P.S. Green, V.H.Heywood, P.-M. Jørgensen, S.L. Jury, S.G. Knees, V.A. Matthews, H.S. Maxwell, D.M. Miller, E.C. Nelson, N.K.B. Robson, S.M. Walters, and P.F. Yeo (eds.). The European Garden Flora. vol. 5. Cambridge Univ. Press, Cambridge, United Kingdom.

Miller, D.M. 1999. Mallow moments. The Garden 124:676-679.

Ray, M.F. 1995. Systematics of Lavatera and Malva (Malvaceae, Malveae)—A new perspective. Plant Systematics and Evolution 198:29_ 53.

Rohlf, F.J. 1992. NTSYS-pc: Numerical taxonomy and multivariate analysis system. Exeter Software, Setauket, N.Y.

Sambrook, E.F., F. Fritsch and T. Maniatis. 1989. Molecular cloning. Cold Spring Harbor Lab. Press, Cold Spring Harbor, N.Y.

Stace, C. 1997. New flora of the British Isles. $2^{\text {nd }}$ ed. Cambridge Univ. Press, Cambridge, United Kingdom.

Van de Laar, H.J. 1991. Keuringen 1991. Dendroflora 28:70-75.

Walker, C.A. and D.J. Werner. 1997. Isozyme and RAPD analyses of Cherokee rose and its putative hybrids 'Silver Moon' and 'Anemone'. J. Amer. Soc. Hort. Sci. 122:659-664.

Welsh, J. and M. McClelland. 1990. Fingerprinting genomes using PCR with arbitrary primers. Nucleic Acids Res. 18:7213-7218.

Williams, J.G.K., A.R. Kubelik, K.J.Livak, J.A. Rafalski, and S.V. Tingey. 1990. DNA polymorphisms amplified by arbitrary primers are useful as genetic markers. Nucleic Acids Res. 18:6531-6535.

Wolff, K. and J. Peters-Van Rijn. 1993. Rapid detection of genetic variability in chrysanthemum (Dendranthema grandiflora Tzvelev) using random primers. Heredity 71:335-341. 